\title{
$\mathrm{C} 214$ 脈波波形に与える呼吸変動の影響 一 脈波波形と呼吸変動の同時連続計測システムの開発 —
}

Effect of respiratory variation for pulse waveform. --- Development of simultaneous and continuous measurement system of respiratory variation and pulse wave. ---

\section{○亀井美讶（岡山大院）正 北脇知己（岡山大院）}

\author{
Okayama University, 2-5-1 Shikatacho, Kita-ku, Okayama-shi, Okayama
}

Key words : pulse wave, respiration, AIx, heart rate

\section{1.はじめに}

近年, 高血圧や肥満, 糖尿病などの生活習慣病の進行や加 齢に伴い, 動脈硬化のリスクが高まっている.これは心筋梗 塞や脳梗塞などの心血管系疾患を引き起こす可能性を大き くしており，予防のためには血管状態を知ることが重要であ る. 血管状態を把握する指標として，脈波波形から算出され る AIx (Augmentation Index) がある ${ }^{(1,2)}$. これは脈波中 の反射波の成分比を表し, 駆出波成分 P1 に対する反射波成 分 P2 の比で表される. 反射波が大きいほど, AIx 值は大き くなり, 動脈硬化が疑われる.また, 動脈硬化による未梢血 管抵抗の増加のため, 心収縮力の増強や末梢からの反射波が 早期に返ってくることから心臓の後負荷が增大し, やがて左 室肥大となりうる. AIx は末梢動脈圧波形から中心動脈圧が 推定できるとされ，このような心負荷の直接的な指標にもな ると考えられている.

上述のように，脈波と臨床との関係は明らかである．しか し, 脈波とその成因との関係はあまり明確にされていない. そのため, 寒冷負荷試験(3)や運動負荷試験(4), Tilt-up 負荷試 験(5)などによる自律神経の変化や，バルサルバ法による物理 的影響, 動物実験といったさまざまな研究がされている. 一 方, 脈波計測の際に, 緊張などによる呼吸性変化によって脈 波変化や基線の動摇がおこり, $\mathrm{AIx}$ 值が大きく変動すること (6)があり，動脈硬化の過小または過大評価となりうる．しか し，こうした呼吸負荷に関する脈波の変動を研究した例は少 ない.このため，脈波波形に与える呼吸変動の影響を解析す ることは, 臨床上で AIx を正確に測定するための手がかりと なると考えられる。

そこで, 本研究では呼吸変動と脈波波形の同時連続測定シ ステムを開発し，このシステムを用いて，呼吸変動が脈波波 形に与える影響の解析が可能かどうかを評価した.

\section{2. 実験方法}

O被験者：健常成人男性 1 名（以下 $\mathrm{M}$ ), 女性 1 名（以下 F) （実験の説明を受け，同意を得ている.)

○姿勢 : 椅座位

○プロトコル

$$
\begin{aligned}
\text { 測定開始 } \sim 120(\mathrm{~s}) \cdots \text { 安静呼吸（安静 I ） } \\
120 \sim 210(\mathrm{~s}) \cdots \text { 深呼吸 } \\
210 \sim 300(\mathrm{~s}) \cdots \text { 安静呼吸（安静 II ) } \\
300 \sim 390(\mathrm{~s}) \cdots \text { 浅い呼吸 } \\
390 \sim 480(\mathrm{~s}) \cdots \text { 安静呼吸（安静 III） }
\end{aligned}
$$

安静呼吸、深呼吸, 浅い呼吸は被験者本人が任意で行う. ○測定システム

脈波波形計測装置（HEM-9000AI，オムロンヘルスケア （株））を用いて，左橈骨動脈の圧脈波波形と押圧力を測定し た。呼吸変動については気流量測定機器（Spirometer,
Vernier Software \& Technology）を用いた.

○同期方法

測定開始 3 秒後と測定終了 10 秒前に, 押圧力の信号と気 流量測定機器内にプログラムした信号を同時に入力するこ とで, 脈波信号と気流量信号を同期させた.

\section{○解析方法}

オムロンヘルスケア(株)のデータ変換ソフトを用いて脈波 波形から AIx, PPI（Pulse Pressure Interval）と，脈波波 形の収縮期血圧，拡張期血圧に対応する値を算出した.

\section{3. 結果}

3.1 被験者 $\mathrm{M}$ について

安静 ( I 〜 III) 時, 深呼吸時, 浅い呼吸時ともに, $\mathrm{AIx}$ と PPI はやや遅れているものの, 呼吸に合わせて変動すること が分かった (Fig. 1).つまり, 吸気時に増加し, 呼気時に減 少した. それに比べて, 血圧の変動も呼吸と連動しているよ うだが, その変化は小さかった. また, 深呼吸時では, AIx , PPI，収縮期血圧において值の変動が大きくなり，その周期 も長くなった（Fig. 2a）.しかし，拡張期血圧には変化がな かった. 一方, 浅い呼吸時では, AIx 洝静 I と変わらなか ったが，PPI は呼吸開始 40 秒後あたりで小さくなった．血 圧は収縮期, 拡張期ともに上昇し, 収縮期血圧の変動周期が 若干長くなった. 安静 ( I 〜 III) を比較すると, 収縮期血圧, 拡張期血圧は安静 I からIIIになるにつれ, 徐々に上昇し, $\mathrm{AIx}$ やPPIには変化はなかった.

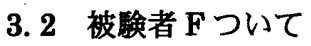

被験者 $\mathrm{M}$ と同様に, AIx と PPI はやや遅れているが, 呼 吸とほぼ連動することが分かった，深呼吸時では，ずへての パラメータにおいて值の変動が大きくなり, その周期はやや 長くなった. また, AIx は徐々に小さくなり, 収縮期血圧は 大きくなった. 一方, 浅い呼吸では, AIxはやや大きくなり 変動周期は短くなった. PPI は, 値には変化がなかったが, 周期は短くなった. 血圧は収縮期, 拡張期とも上昇した。 ま た, 安静呼吸（I〜III）を比較すると, 血圧值はどちらも安 静 I からIIIになるにつれて, 上昇したが，安静而の 40 秒後 あたりから徐々に下がっていた. AIx やPPIには変化はなか つた.

\section{4. 考察}

本研究で開発した測定システムを用いることで, 脈波波形 と呼吸変動を同時に測定することができた. そして, 被験者 間でみられる呼吸変動の脈波波形に与える影響が異なるこ とが分かった. しかし，深呼吸を行うと值の変動が大きくな ることは共通した. さらに，両者ともに浅い呼吸時に血圧が 高くなっていたが, この変化は換気量の減少により交感神経 


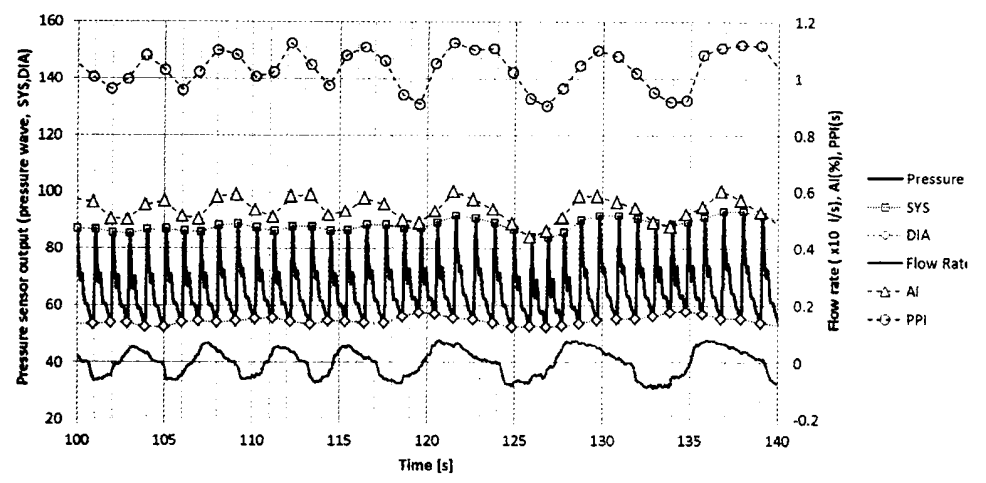

Fig.1 Simultaneous measurement results of pulse waveform and flow rate.

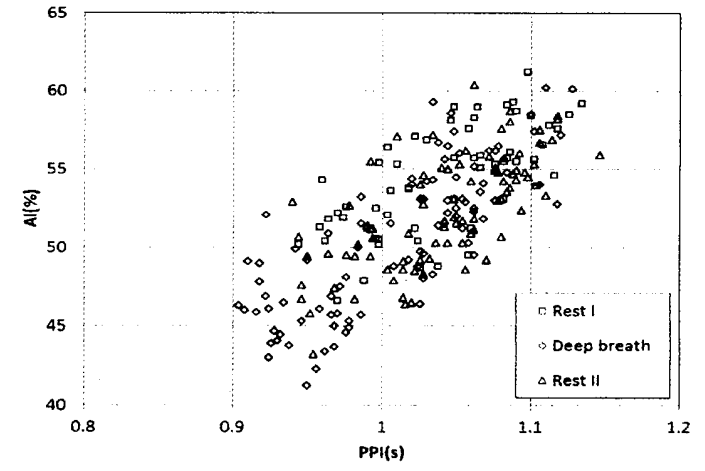

Fig.3 Relationship between AIx and PPI.
が優位になったことから説明可能である.

$\mathrm{AIx}$ と PPI は正の相関（Fig. 3）を示していた.これは Wilkinson らの研究 ${ }^{(7)}$ と同様の結果であり, 呼吸変動によ り誘起された PPI の変化と AIx が関連していることが示さ れた.

浅い呼吸による脈波波形の変化は深呼吸時よりも乏しい ものだった.この原因としては呼吸の加減が難しく, 安定し た負荷がかけられなかったことが考えられた。また，実際に 被験者 Mの一回換気量を算出する（Fig. 2b）と，被験者本 人の思うほど浅い呼吸ができていないことが示されている.

被験者 $\mathrm{F}$ は浅い呼吸時とその後の安静呼吸時の脈波波形 の変化に違いがあまりなかった.これはリラックスして測定 ができていなかった可能性が考えられた。

\section{5. 結詥}

本研究では, 呼吸変動と脈波波形の同時連続測定システム を開発し, 脈波波形 に与える呼吸変動の 影響について解析し た.被験者によって， 呼吸変動の影響は異 なっていたが, 両者 とも PPIやAIx 流量の増減に合わせ て変化することが分 かった. 特に, 深呼 吸時にはこの変化が 著明にあらわれ, 浅 い呼吸による脈波波 形の変化は深呼吸時 よりも乏しいものだ った.これは浅い呼 吸の加減が難しかっ たためだと考えられ た.

今後は被験者を増 やすとともに, 指示 された呼吸法がしや すいように気流量を 可視化できるシステ ムについて検討する. さらに, 本研究でみ られた脈波波形の変 化についても研究を 進めていきたい.

\section{参考文献}

(1) R Kelly et al. Circulation. 1989; 80 1652-1659.

(2) Miranda T. Schram et al. Hypertension. 2004; 43 176-81.

(3) Casey DP et al. Eur JAppl Physiol. 2008; 103 539-43.

(4) B. Dischl et al. Scand J Med Sci Sports. 2011: 21 e325-e333.

(5) Karin Toska, Lars Walløe. J Appl Physiol. 2002; 92 1671-1676.

(6)「Central Blood Pressure (中心血圧) Augmentation Index（AI）正確な測定結果を得るために」，オムロンへ ルスケア(株)

(7) Ian B. Wilkinson et al. Am $J$ Hypertens $2002 ; 15$ $24-30$.

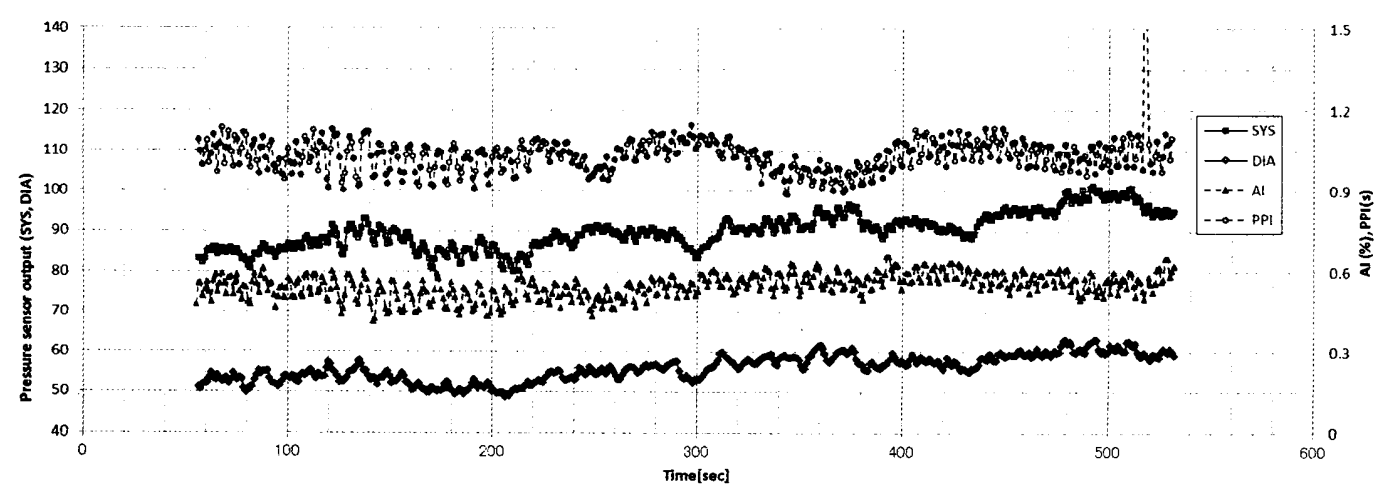

(a) Parameters from pulse waveform

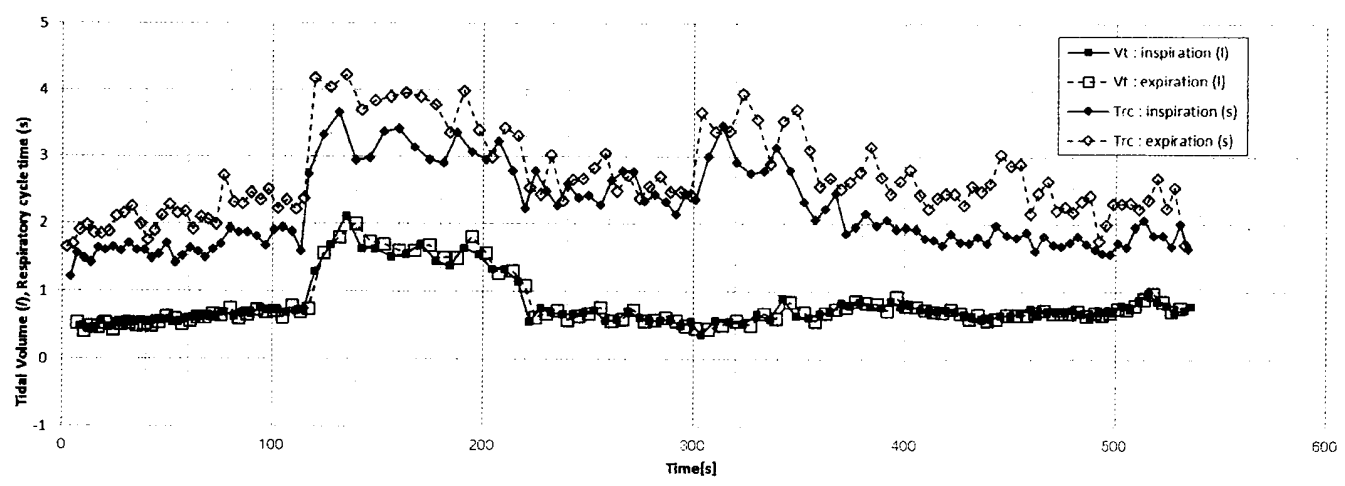

(b) Parameters of resipiration 